\title{
The Response of the Pulp-Dentine Complex, PDL, and Bone to Three Calcium Silicate-Based Cements: A Histological Study in an Animal Rat Model
}

\author{
Ranjdar Mahmood Talabani $\mathbb{D D}^{1}$ Balkees Taha Garib $\mathbb{D D}^{2},{ }^{2}$ and Reza Masaeli $\mathbb{D D}^{3}$ \\ ${ }^{1}$ Conservative Department, College of Dentistry, University of Sulaimani, Sulaimani-Dream Land B-25, Sulaymaniyah, \\ Kurdistan Region, Iraq \\ ${ }^{2}$ Oral and Maxillofacial Medicine in Kurdistan Board of Dental Specialties, Department of Oral Diagnosis, College of Dentistry, \\ University of Sulaimani, Sulaymaniyah, Kurdistan Region, Iraq \\ ${ }^{3}$ Department of Dental Biomaterials, School of Dentistry, Tehran University of Medical Sciences, Tehran, Iran \\ Correspondence should be addressed to Ranjdar Mahmood Talabani; ranjdar.osman@univsul.edu.iq
}

Received 13 September 2019; Revised 28 December 2019; Accepted 3 January 2020; Published 13 April 2020

Academic Editor: Guillermo Mendoza-Diaz

Copyright (c) 2020 Ranjdar Mahmood Talabani et al. This is an open access article distributed under the Creative Commons Attribution License, which permits unrestricted use, distribution, and reproduction in any medium, provided the original work is properly cited.

Objective. The aim of this study was to histologically examine the tissue reaction of three different calcium silicate cements in the closure of perforations in rat incisor teeth. Material and Methods. An experimental lateral root perforation with pulp exposure was performed in 32 lower incisors of 16 male Wistar albino rats. They were randomly assigned into three test groups (each including eight teeth) that were filled either by Biodentine (BD) or MicroMega mineral trioxide aggregate (MM-MTA) or EndoSequence root repair material putty (ESRRM putty), besides eight unperforated incisors from the other four rats (control group). The inflammatory response and healing process were evaluated histologically and scored after one and four weeks. Differences among groups were tested by Kruskal-Wallis tests at $P \leq 0.05$. Results. In the first week, BD produced more inflammatory response in the pulpal (score 3) than other materials (score 2). Only ESRRM putty showed odontoblast-like cells in 50\%, 25\% dentine-like deposit, $25 \%$ evidence of bone deposition in the drilling site (score 2), and minimum periodontal ligament (PDL) necrosis and disorganization (25\%, score 2). After one month, all groups had healthy pulpal tissue, but $25 \%$ of ESRRM putty retained score 1 inflammatory response, and $50 \%$ of the BD case had an incomplete palisading odontoblast layer (score 3 ). A thick and regular dentine bridge deposition was seen in the ESRRM putty group in comparison with MM-MTA and BD cases. The cortical plate healing in all ESRRM putty samples was complete (score 3), while an incomplete closure was seen in MM-MTA and BD groups (score 2). Both the MM-MTA and ESRRM putty groups had fully organized PDL (score 2), while in 50\% of BD cases, a necrotizing area and disorganized PDL with inflammatory cells infiltration were still present. Statistically significant differences in the scores of any histologic parameters among the three tested materials were observed neither in the 1st nor in the 4th weeks of the experimental period. Conclusion. Better tissue compatibility and repair of pulpal and periodontal tissue have been detected after lateral perforation in the root of rat incisors when treated with ESRRM putty than MM-MTA and BD. However, the difference was not significant.

\section{Introduction}

Root perforation is a communication between the root canal system and the surrounding tissues through the floor of the pulp chamber or root canal wall of the tooth [1]. It can occur as a result of a large carious lesion in or adjacent to the floor of the pulp chamber, resorptive defects, or iatrogenic factors (i.e., procedural errors or accident) during endodontic treatment [2]. Several factors may interfere with the repair of the defect and, at the same time, affect prognosis [3]. The long-term prognosis of a perforated tooth is dependent upon the location of the perforation, how long the perforation is exposed to oral contamination, and the ability to seal the hole [4]. When a pulp chamber floor perforation occurs, the 
periodontal ligament (PDL) and the bone tissue are destroyed in variable intensity. The inflammatory process is established, and the risk of the possibility of epithelial proliferation, periodontitis, and progressive alveolar process of bone destruction is increased.

Moreover, if inappropriately treated, perforations could lead to poor prognosis and subsequent tooth loss [5]. Wound healing with reparative mineralized tissue formation represents the optimal end result of treatment; tissue regeneration depends on several host and treatment factors. One of the reasons why perforations tend to have such poor prognosis may be the fact that none of the materials used can accomplish tissue regeneration at the treated site $[6,7]$. Calcium silicate-based cement has been considered to be the best choice to seal dentinal defects between the pulp space and the periodontal ligament, as well as a root-end filling after endodontic surgeries $[8,9]$.

Calcium silicate-based cements have been developed more than 20 years ago with Mineral Trioxide Aggregate as endodontic repair and root-end filling materials [10-12]. Due to their biocompatible properties $[13,14]$, their clinical usage rapidly expanded towards direct and indirect pulp capping [15], taking into consideration some disadvantages associated with classic MTA formulations such as long setting time, difficulty in handling, poor mechanical properties, and tooth discoloration $[10,16]$. Moreover, there is evidence that bismuth oxide used as radiopacifier inhibits cell proliferation [17]. Newer calcium silicate cements have been developed with enhanced physicomechanical and handling properties. MicroMega MTA (MM-MTA; MicroMega Besanchon, France), another formulation of MTA, was developed in 2011 to overcome drawbacks of the original MTA products. It is an injectable osteoconductive, osteoinductive, and biocompatible tricalcium silicate-based cement and also contains calcium carbonate, which helps in reducing the setting time [18].

Biodentine (BD) (Septodont, Saint Maur de Fosses; France) was developed in 2009 as a novel tricalcium silicatebased cement [19]. It was described as a bioactive dentine substitute due to having similar mechanical properties to dentine. Also, it can be used with similar indications to MTA $[8,20]$. Following the induction of a moderate inflammatory reaction in rat subcutaneous tissue, $\mathrm{BD}$ presents a significant reduction of this response over time, similar to MTA [21]. $\mathrm{BD}$ has shown better biological properties than other tricalcium silicate cements such as MTA in in vitro studies in cultures of osteoblasts, periodontal ligaments fibroblasts, and pulp [22, 23]. In addition, BD significantly released more calcium ions with deeper incorporation into the root canal dentine than MTA, hence leading to the formation of a "mineral infiltration zone" [24]. This cement also induces the formation of mineralized tissue sealing furcation perforations in teeth of dogs [25] and dentine bridge formation after pulp exposure of human teeth [8].

An alternative material, EndoSequence Root Repair Material putty (ESRRM putty), was developed as a premixed, injectable material formulated using bioceramic technology. It has been released by Brasseler USA (Savannah, GA) to be used as a clinical replacement for MTA. ESRRM putty has the advantages of faster setting and superior handling properties [26]. Different in vivo studies in rat subcutaneous tissue [27] and in vitro studies on human gingival fibroblast [28] and L929 mouse fibroblasts [29] reported that ESRRM putty showed similar biocompatibility to MTA. Moreover, ESRRM has been found to promote the healing of dental tissue and show similar survival and proliferation of dental pulp cells to MTA using different assays [30]. So, this study aims to investigate and compare the repairing ability of MMMTA, ESRRM putty, and BD in the modulation of the inflammatory process of pulp, PDL, bone remodeling, odontoblastic differentiation, and dentine bridge formation after lateral perforations in rat incisors. In the null hypotheses, none of the calcium silicate-based materials tested in this study has the ability to repair and/or regenerate pulp, PDL, dentine, and bone when applied on lateral perforations in rat incisors.

\section{Material and Methods}

This study was performed in accordance with the principles of laboratory animal care (NIH publication 85-23, 1985). The national laws on animal use were also observed for the present study by getting authorization from the Ethical Committee for Animal Research of Sulaimani University (no. 9, 6.2.2017).

Sixteen male Wistar albino rats, aged 4-5 months and weighing $250-350 \mathrm{~g}$, with a total of 32 lower incisor teeth, were used in this study. The rats were maintained in individual stainless steel cages under a 12:12 light-dark cycle at controlled temperature $\left(21 \pm 2 \mathrm{C}^{\circ}\right)$ and humidity $(55 \pm 10 \%)$, with food and water provided ad libitum, in the animal house at Farabi Comprehensive Center of Excellence in Ophthalmology, Tehran University of Medical Sciences, Qazvin Square, Tehran, Iran.

The rats were anesthetized with an intraperitoneal injection of ketamine $75 \mathrm{mg} / \mathrm{Kg}$ of body weight combined with xylazine $10 \mathrm{mg} / \mathrm{Kg}$ of body weight. After localizing the site of perforation with a pen marker, an intraoral approach was used to perform the mechanical root perforation of lower rat incisors on the distal border of the labial surface of the root, $5-6 \mathrm{~mm}$ below the gingival margin, using a sterile type 2 small-size long-shank carbide round bur on a straight lowspeed handpiece with copious saline irrigation. The size of the perforation was standardized to the diameter of the bur head in width $(1.5-2-\mathrm{mm})$ and its depth determined by penetration into the pulp canal. After hemostasis with distilled water and sterile cotton pellet, three calcium silicate-based materials, Biodentine ${ }^{\mathrm{TM}}$ (Septodont, St-Maurdes-Fossés, France) (Lot No. 5024200U0), MicroMega MTA (MM-MTA; MicroMega Besanchon, France) (Lot no. 71708614), and EndoSequence Root Repair Material putty (Brasseler USA, Savannah, GA) (Lot no. B19585), were used. The composition of the test materials is shown in Table 1. BD was prepared according to the manufacturer's recommendations and inserted into the perforated site of eight right lower rat incisors with amalgam carrier (Shanghai, China) and condensed using a small-sized ash condenser (Shanghai, China). MM-MTA in an available capsule form was 
TABle 1: Composition of calcium silicate-based cements used in this study.

\begin{tabular}{|c|c|c|c|}
\hline Material & Manufacturer & The composition according to the manufacturer & Lot no. \\
\hline MM-MTA & $\begin{array}{l}\text { MicroMega, Besançon, } \\
\text { (France) }\end{array}$ & $\begin{array}{l}\text { Powder: tricalcium silicate, dicalcium silicate, tricalcium aluminate, bismuth } \\
\text { oxide, calcium sulfate dehydrate, and magnesium oxide. Liquid: calcium } \\
\text { carbonate }\end{array}$ & 71708614 \\
\hline $\begin{array}{l}\text { ESRRM } \\
\text { putty }\end{array}$ & $\begin{array}{l}\text { Brasseler, Savannah, GA, } \\
\text { USA }\end{array}$ & $\begin{array}{l}\text { Tricalcium silicate, dicalcium silicate, calcium phosphate monobasic, calcium } \\
\text { hydroxide, colloidal silica, and water-free thickening agent }\end{array}$ & B19585 \\
\hline Biodentine & $\begin{array}{l}\text { Septodont, Saint Maur des } \\
\text { Fosses, France }\end{array}$ & $\begin{array}{l}\text { Powder: tricalcium silicate }\left(\mathrm{Ca}_{3} \mathrm{SiO}_{5}\right) \text {, dicalcium silicate }\left(\mathrm{Ca}_{2} \mathrm{SiO}_{4}\right) \text {, calcium } \\
\text { carbonate }\left(\mathrm{CaCO}_{3}\right) \text {, iron oxide }\left(\mathrm{Fe}_{2} \mathrm{O}_{3}\right) \text {, and zirconium oxide }\left(\mathrm{ZrO}_{2}\right) \text {. Liquid: } \\
\text { Water }\left(\mathrm{H}_{2} \mathrm{O}\right) \text { with calcium chloride }\left(\mathrm{CaCl}_{2}\right) \text { and soluble polymer } \\
\text { (polycarboxylate) }\end{array}$ & $5024200 \mathrm{U} 0$ \\
\hline
\end{tabular}

prepared according to the manufacturer's instructions and inserted into the perforations, while ESRRM putty was directly inserted into the holes.

The thirty two lower incisor teeth were divided into 3 experimental groups according to the perforation repair material: $\mathrm{BD}(n=8 /$ right side) or MM-MTA ( $n=8 /$ left side) or ESRRM putty ( $n=8 /$ right side) and one control group $\left(n=8 /\right.$ left side) with no perforation. On the $1^{\text {st }}$ and $4^{\text {th }}$ week after filling the perforations, the animals ( $n=4$ per group/ period) were euthanized by carbon dioxide. The mandibles were removed with the perforated root of the lower incisor and its surrounding periodontal tissues immersed in a fixative solution.

The graphically detailed description of the surgery procedure and photographs of the appearance of the implantation site and excision of specimens are shown in Figure 1.

Procedures for the paraffin-embedding and histological evaluation:

The specimens were fixed in $10 \%$ buffered formalin solution at $\mathrm{pH} 7.2$ at room temperature for 48 hours. After decalcification for $4-5$ weeks in $10 \%$ formic acid with $0.5 \%$ formaldehyde buffered at $\mathrm{pH} 7.2$, the specimens were dehydrated in graded concentrations of ethanol. Then, they were cleared in xylene and embedded in paraffin. Sections of $5 \mu \mathrm{m}$ thickness were prepared and stained with hematoxylin and eosin (H\&E) for histological studies.

The stained sections were blindly evaluated by two experienced pathologists. Under a light microscope (Olympus, Tokyo, Japan) at $\times 4, \times 10$, and $\times 40$ magnifications, all samples were evaluated and scored in terms of pulpal inflammatory response, odontoblast differentiation and dentine bridge formation, calcified bone formation, and continuity and organization of PDL and scored according to criteria modified from Liu et al. [31], Salman et al. [32], and Moreton et al. [33] Table 2.

2.1. Statistical Analysis. Statistical analyses were performed using SPSS version 22 software (SPSS, Chicago, IL, USA). The effect of regeneration and repairing on the properties of three calcium silicate-based cements and significant differences between mean were evaluated by using the Kruskal-Wallis test. The level of significance was $P \leq 0.05$.

\section{Results}

The results of the mean value scoring for pulp and periodontium response are presented in Table 3. In the first week, sections showed that, in all BD implanted samples, the pulp contained hyperemia, numerous congested capillaries, and an area of necrosis (score 3) (Figure 2). The other tested materials had a mild pulpal response (score 2). They presented moderate hyperemia with less than five congested capillaries per field and high cellularity within a dense fibrous pulpal tissue (Figures 3 and 4).

The drilling procedure and material implantation resulted in odontoblast cell layer destruction (score 0 ) in all groups (Figures 2 and 3 ) except in $50 \%$ cases in the ESRRM putty group, where a few cuboidal cells were seen adjacent to the implanted materials (score 1) (Figure 4). Within this period, no experimental evidence in the $\mathrm{BD}$ group indicated dentine bridge formation (score 0) (Figure 2), and 25\% of cases in ESRRM putty and MM-MTA groups showed such deposition (score 1) (Figures 3 and 4).

Gaps in all groups were unclosed; however, signs of material deposits could be seen at the cut edge of the bone in BD and MM-MTA samples (100\% score 1) (Figures 2 and 3), with $25 \%$ (score 2) of ESRRM putty samples showing evidence of bone deposition (Figure 4). All groups showed a visible area of necrosis and disorganized PDL infiltrated by chronic inflammatory cells (score1). Nevertheless, the ESRRM putty group had nonsignificant necrosis and inflammation (25\% at score 2). Seepage of a small increment of ESRRM putty within PDL was devoid of necrosis and surrounded by vital fibrous tissue (Figure 4).

At the end of the experiment (after one month), the dental pulp in a few cases of ESRRM putty showed less than five congested capillaries per field (25\% in score 1$)$. The score for the remaining groups was zero. Both ESRRM putty and MM-MTA groups completely retained the complete palisading pattern of odontoblasts (score 3), while $50 \%$ of BD cases showed a partial, incomplete palisading cell pattern (mean score 2.5). The best repair for dentine was presented in the ESRRM putty group, with the results showing thick, regular, and complete dentine formation (score2). Meanwhile, an incomplete and thin irregular dentine bridge was noticed in all cases of the MM-MTA group as well as $75 \%$ of $\mathrm{BD}$ cases (mean score, 1.3) (Figures 5-7). 


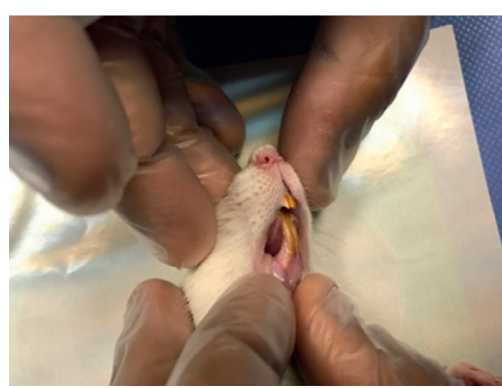

(a)

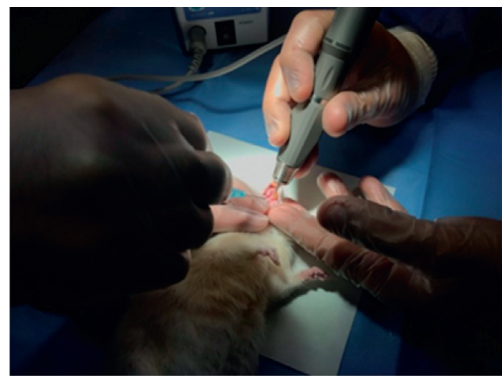

(d)

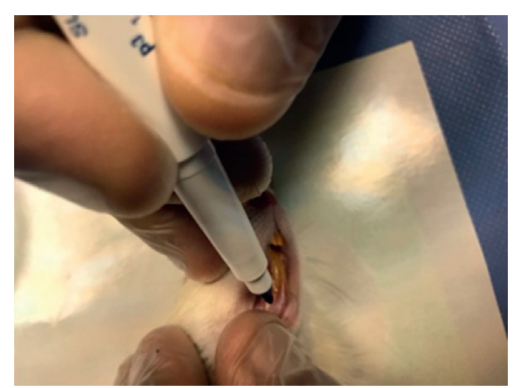

(b)

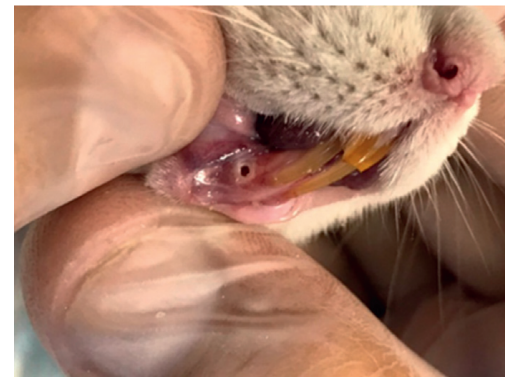

(e)

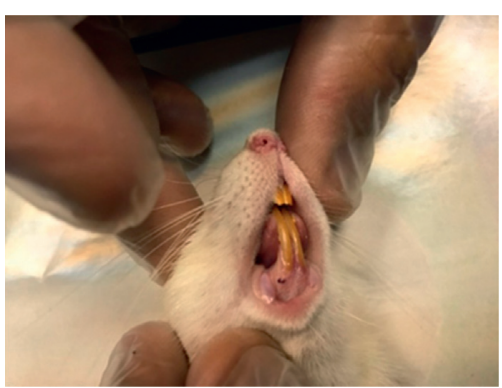

(c)

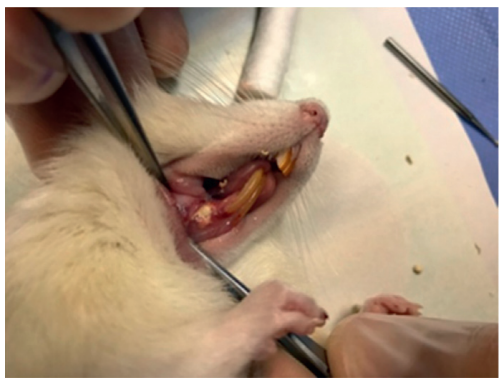

(f)

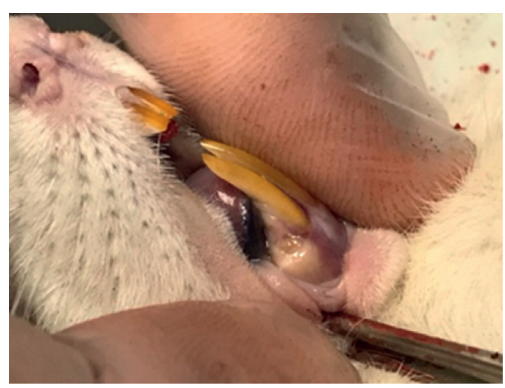

(g)

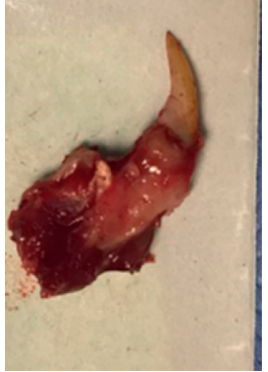

(h)

Figure 1: The surgical procedure: (a) lower rat incisor teeth, (b and c) localization of perforation site, (d) surgical perforation procedure, (e) implantation site, (f) material implantation, (g) implantation follow-up evaluation, and (h) excised implantation with surrounding tissues.

TABLE 2: Evaluation criteria for the histopathological analysis of pulp-dentine complex, PDL, and bone responses after lateral root perforation and mechanical pulp exposure in rats.

\begin{tabular}{lccc}
\hline 0 & 1 & 2 & 3 \\
\hline $\begin{array}{l}\text { Inflammatory cell infiltration of the pulp } \\
\text { No necrosis, No hyperemia } \\
\text { (no blood vessels and } \\
\text { congestion) }\end{array}$ & $\begin{array}{c}\text { No necrosis, normal cellularity, and a } \\
\text { minimum amount of blood vessels } \\
(<5)\end{array}$ & $\begin{array}{c}\text { No necrosis, moderate hyperemia, and } \\
\text { congestion ( }>5 \text { blood vessels) with high } \\
\text { cellularity (dense fibrous and fibrotic) }\end{array}$ & $\begin{array}{c}\text { Necrosis and severe } \\
\text { congestion and } \\
\text { hyperemia }\end{array}$ \\
\hline $\begin{array}{l}\text { Odontoblast and odontoblastic cell layer } \\
\text { Presence of odontoblastic-like cells } \\
\text { only }\end{array}$ & $\begin{array}{c}\text { Partial, incomplete palisading cell pattern } \\
\text { Complete palisading } \\
\text { cell pattern }\end{array}$ \\
\hline $\begin{array}{l}\text { Dentine bridge formation: } \\
\text { No hard tissue deposition }\end{array}$ & $\begin{array}{c}\text { Incomplete (partial or thin irregular } \\
\text { D. bridge formation) }\end{array}$ & $\begin{array}{c}\text { Thick, regular, and complete dentine } \\
\text { associated with hard tissue formation }\end{array}$ \\
\hline $\begin{array}{l}\text { Bone (calcified bone barrier continuity) } \\
\text { No calcified bone barrier } \\
\text { formation (deposition) }\end{array}$ & $\begin{array}{c}\text { extending to no more than one-half } \\
\text { of the exposure site }\end{array}$ & $\begin{array}{c}\text { Partial, incomplete calcified bone formation } \\
\text { extending to }>1 / 2 \text { of exposure site but not } \\
\text { completely closing the exposure site }\end{array}$ & $\begin{array}{c}\text { Complete calcified } \\
\text { bone formation }\end{array}$ \\
\hline $\begin{array}{l}\text { Periodontal ligament response } \\
\text { Necrosis disorganized PDL with } \\
\text { inflammation }\end{array}$ & $\begin{array}{c}\text { Fully organized PDL with no necrosis and } \\
\text { inflammation }\end{array}$ \\
\hline
\end{tabular}


TABLE 3: The mean score values of the pulp-dentine complex and periodontium response in the 1st and 4th weeks intervals after filling a lateral root perforation with three types of calcium silicate-based cement.

\begin{tabular}{|c|c|c|c|c|c|c|c|c|c|}
\hline \multirow[b]{2}{*}{ Parameters } & \multirow[b]{2}{*}{ Score range } & \multicolumn{4}{|c|}{$1^{\text {st }}$ week } & \multicolumn{4}{|c|}{4 th week } \\
\hline & & $\mathrm{BD}$ & $\begin{array}{l}\text { MM- } \\
\text { MTA }\end{array}$ & ESRRM putty & $P$ value & $\mathrm{BD}$ & $\begin{array}{l}\text { MM- } \\
\text { MTA }\end{array}$ & ESRRM putty & $P$ value \\
\hline Pulpal response & $(0-3)$ & $3(100 \%)$ & $2(100 \%)$ & $2(100 \%)$ & 0.135 & $0(100 \%)$ & $0(100 \%)$ & $0.33(25 \%)$ & 0.607 \\
\hline Odontoblast & $(0-3)$ & $0(100 \%)$ & $0(100 \%)$ & $0.5(50 \%)$ & 0.472 & $2.5(50 \%)$ & $3(100 \%)$ & $3(100 \%)$ & 0.47 \\
\hline Dentine bridge formation & $(0-2)$ & $0(100 \%)$ & $1(25 \%)$ & $1(25 \%)$ & 0.819 & $1.33(75 \%)$ & $1(100 \%)$ & $2(100 \%)$ & 0.189 \\
\hline Calcific bone barrier & $(0-3)$ & $1(100 \%)$ & $1(100 \%)$ & $1.33(25 \%)$ & 0.135 & $2(100 \%)$ & $2(100 \%)$ & $3(100 \%)$ & 0.082 \\
\hline PDL & $(1-2)$ & $1(100 \%)$ & $1(100 \%)$ & $1.33(25 \%)$ & 0.513 & $1.5(50 \%)$ & $2(100 \%)$ & $2(100 \%)$ & 0.472 \\
\hline
\end{tabular}

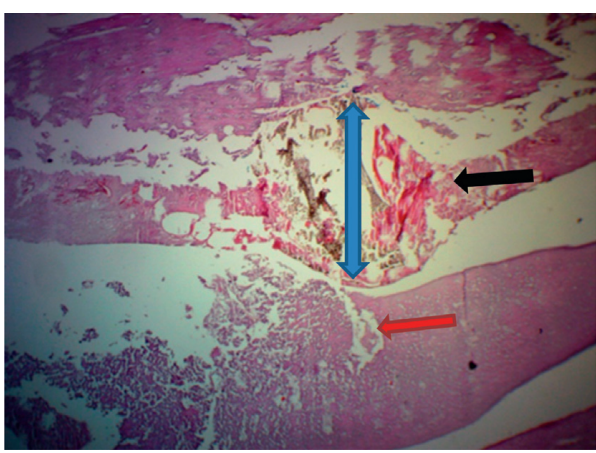

(a)

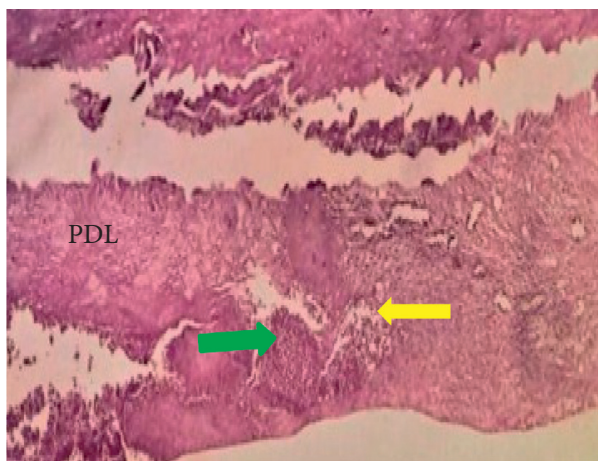

(c)

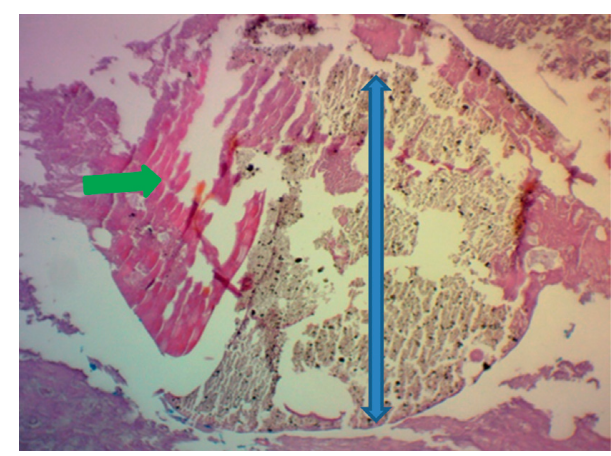

(b)

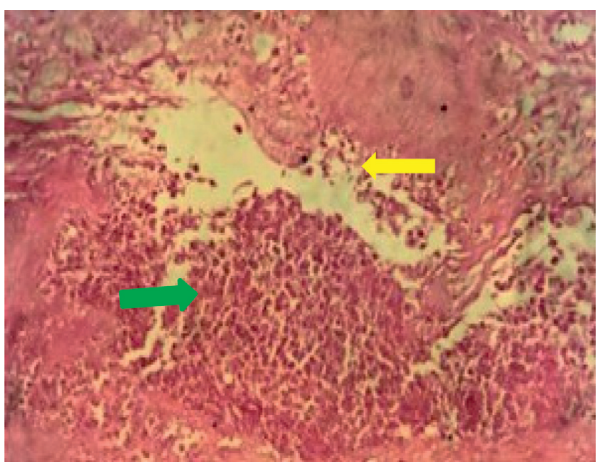

(d)

Figure 2: Photomicrograph of an H\&E-stained tissue section through the incisor of a rat after 1 week Biodentine (blue up-down arrows) treatment. (a) Longitudinal section showed a gap in dentine (red arrow) and distortion in the pulp (black arrow) (40X). (b) Higher magnification of the necrotic zone (green arrows) in the pulp around BD (100X). (c and d) Severe inflammation (yellow arrows.), localized distortion, and necrosis (green arrow) in the PDL (100X and 400X).

Considering the periodontium, all samples of ESRRM putty were associated with calcified bone that completely closed the exposure site (score 3) (Figure 7) in comparison to the partial, incomplete, and noncompact bone deposition extending across less than $1 / 2$ of the drilling site as identified in the BD and MM-MTA groups (score 2) (Figures 5 and 6). Furthermore, both MM-MTA and ESRRMs putty groups had fully organized PDL with no necrosis or inflammation (score 2) (Figures 6 and 7), while in $\mathrm{BD}$ (mean score 1.5 ), 50\% of cases showed a necrotizing area with disorganized PDL and inflammatory cells infiltration (Figure 5).

Figure 8 shows healthy nonperforated lower rat central incisors, in which the dental pulp exhibits dilated congested blood vessels with multiple layers of palisading columnar odontoblast. The alveolar bone contains osteocyte and PDL attached to thin cementum.

No statistical differences $(P \geq 0.05)$ were observed during the 1 st and 4 th weeks of the experimental period in the scores of any of the histologic parameters that monitored pulp-dental and periodontium response to the three different types of calcium silicate-based cement (BD, MMMTA, and ESRRM putty) (Table 3).

\section{Discussion}

Prognosis of root perforation depends on the site, size of the hole, the adjacent periodontal conditions, and sealing materials $[4,34,35]$. The choice of a proper sealing material to seal pathologic or accidental root perforations has a decisive 


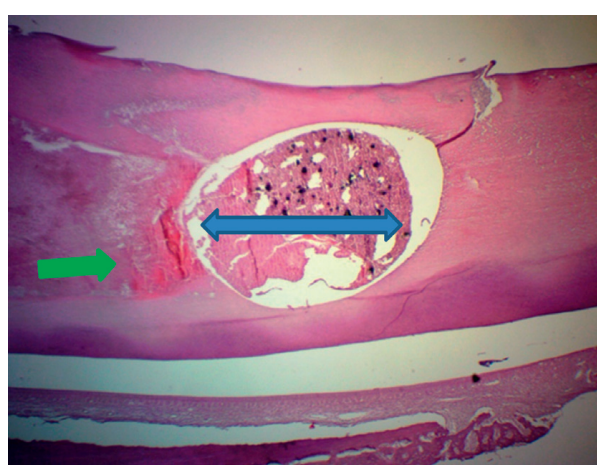

(a)

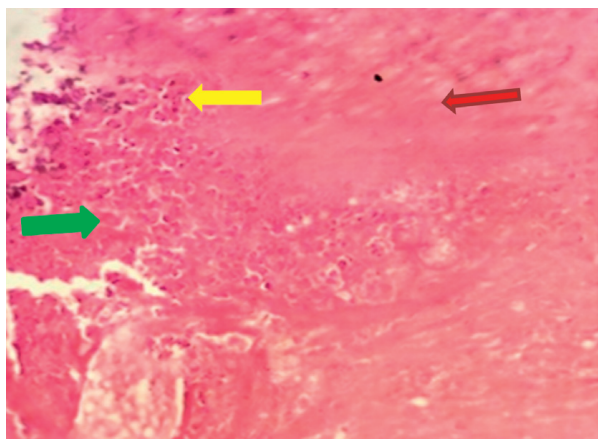

(c)

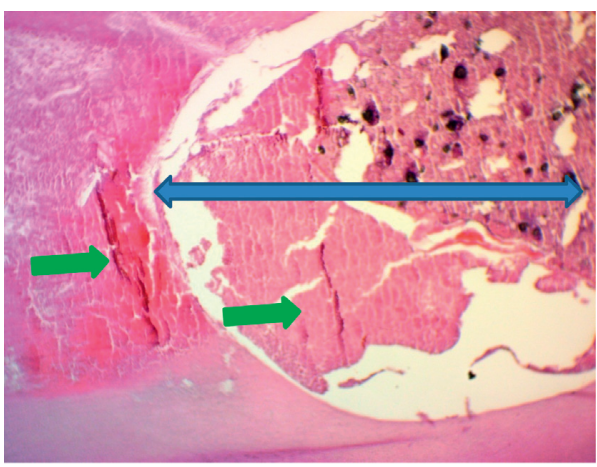

(b)

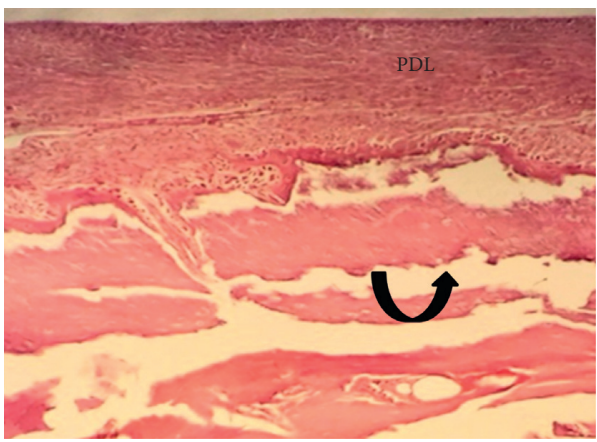

(d)

Figure 3: Microphotographs of an H\&E-stained longitudinal section for the pulp and periodontium response in the central incisor after 1 week of MM-MTA treatment (blue left-right arrows). (a) (40X) and (b) (100X): evidence of inflammation, necrosis (green arrows) and calcification within the pulp. (c) Irregular dentine (red arrow) deposition (100X). (d) The periodontal ligament had unorganized fibrous tissue and congested capillaries with inflammatory cells infiltration (yellow arrow, 40X). Small woven bone trabeculae (black curved-up arrow) presented at the interface with PDL.

role in the repair of these lesions [36]. This depends on the biocompatibility and bioactivity of the materials promoting the healing process, preserving the vitality of pulp as well as continuing formation of the dentine bridge [25, 37-39], stimulating the repair of the periodontal ligament [40] and regenerating the bone [41].

Clinical studies are essential as they allow inferences about the symptoms and radiographic observation of repaired or unrepaired areas surrounding the periodontal supporting tissues $[42,43]$. However, they do not assess tissue responses, which should be the base for accurate material testing, helping to determine the best treatment protocols $[1,2,44]$. Several authors, in assessing the effect of dental materials on pulpal and periodontal tissue responses, have used animal models such as rats [45, 46], although the teeth of dogs and monkeys present size and morphology that facilitate access, visualization, and control of the material to seal perforations [44, 47, 48]. Nonetheless, we found that rats have biological similarities with humans as well as a faster metabolism which reduces the time of research and should, therefore, be considered a practical model for comparing the effects of various materials $[45,46]$.

In this experiment, designing the lateral perforation in the root of rats' incisors as a model to study dental and paradental hard and soft tissues' response was a pioneering procedure. It adds new knowledge on the biological effects of
ESRRM putty in promoting the healing process of experimental perforation related to pulp viability, dentine formation, and bone calcification. Furthermore, it provides simultaneous testing and comparison of the effect of the three calcium silicate-based cements on the inflammatory reaction and regeneration of the pulp-dentine complex and periodontium adjacent to MM-MTA, BD, and ESRRM putty in one model over two different periods. In comparison with previous authors who used the pulp chamber and furcation area of rat molars to assess periodontal and periapical tissue responses to dental materials $[45,47,49]$, we showed that the implantation of tested materials in the root of rat incisors is an acceptable and valuable in vivo model. It allows the study of pulpal and periodontium tissue structures and reactions within a single organ and representing the whole life cycle of cellular activity from formation to maturation and repair after the injury as a result of its nature in continuous growth and eruption. Besides, it gives more accessibility with better amounts of bone and PDL to assess the response in comparison to the furcation area or labial-lingual approaches $[50,51]$.

In this study, we reproduced the biological pulpal response after root perforation. Both ESRRM putty and MMMTA showed mild inflammation and moderate hyperemia in comparison to $\mathrm{BD}$ which showed more congestion and severe inflammatory response with necrosis. The presence of 


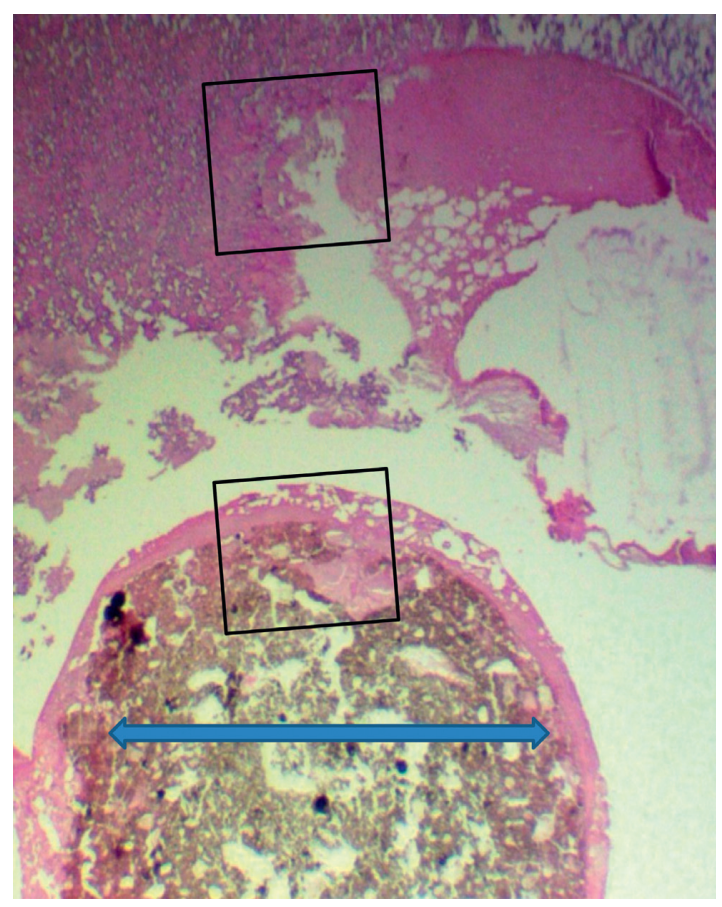

(a)

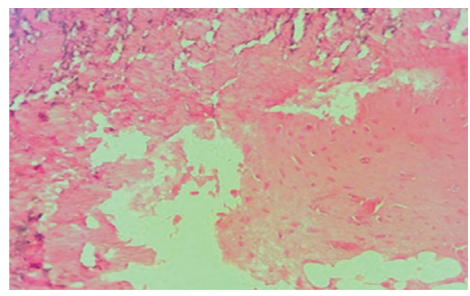

(c)

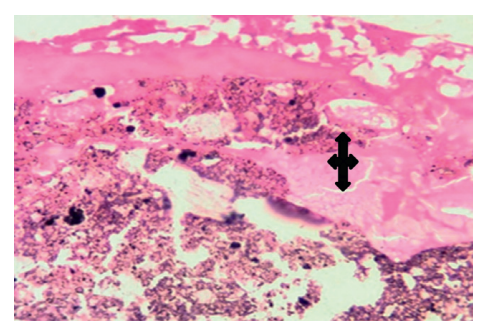

(b)

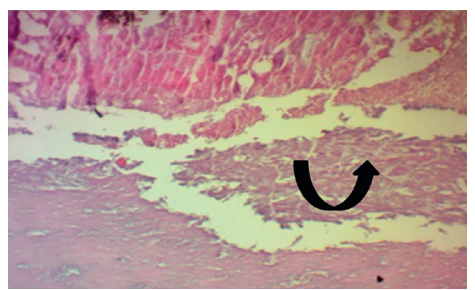

(d)

FIgURE 4: Microphotographs of a longitudinal H\&E-stained section through central incisor after one week of ESRRM putty treatment. (a-c) The ESRRM putty (blue left-right arrow) surrounded by and incorporating mineralized deposition pulpal tissue contained a few long dilated and congested blood vessels, and an irregular deposition of reparative dentine (quad arrow) was seen adjacent to multilayers of short odontoblasts ((a) 40X; (b-c) 100X). d: The periodontal ligament had dense fiber bundles running parallel to the root surface and inserted in the newly formed bone with minimum congested capillaries with no inflammatory cells infiltration (100X). The gap in the alveolar bone was filled with irregular and small bone trabeculae (black curved-up arrow).

a thin necrotic layer in the pulp of the root treated with $\mathrm{BD}$ (score 3) may be due to the released hydroxyl ions that upon hydration increased the $\mathrm{pH}$. This necrotic area protects the underlying vital pulp cells from the material's alkaline $\mathrm{pH}$. Furthermore, it allows the underlying pulp cells to carry out the healing and regeneration functions [52]. However, at the end of the experiment, there were no remarkable differences among the tested materials. The outcome of this study indicates that iatrogenic pulp defects treated with any of the three calcium silicate cements are principally free from serious degenerative tissue reaction after one month of the experiment. These findings are in accordance with the previous investigation that separately found ESRRM putty to be as biocompatible as MTA [53-55], and higher inflammatory response was seen in $\mathrm{BD}$ compared with MTA that decreased with time $[8,56]$.

Otherwise, the existence of the specialized highly differentiated cells (odontoblasts) is crucial during pulp inflammation and trauma. In the best circumstances, at the area of injury, the degenerated cells can be replaced by new odontoblast-like cells that start to form a protective dentine layer [57]. Thus, in the absence of pulpal inflammation, the process of reparative dentinogenesis with complete or partial closing of perforations with dentine-like hard tissue bridges formation was interpreted as a positive reaction to stimulation and as a sign of healing. In this research, the dentine bridge was observed in all samples of ESRRM putty, with better deposition in the BD and MM-MTA groups; however, the differences were not in a statistically significant level. Furthermore, just below the newly formed dentine bridge, the odontoblasts-like palisade cells were also evident in most of the three experimental groups after four weeks, with minor or major structural changes that ranged from mild to complete organization.

The superiority of ESRRM putty over MM-MTA in pulp repair and stimulated dental pulp stem cell proliferation, especially at the beginning of the study, was attributed to its granular topology [58], alkalinity [59], high alkaline 


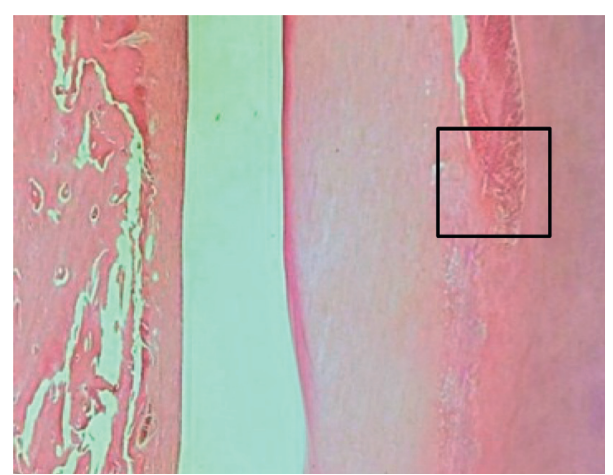

(a)

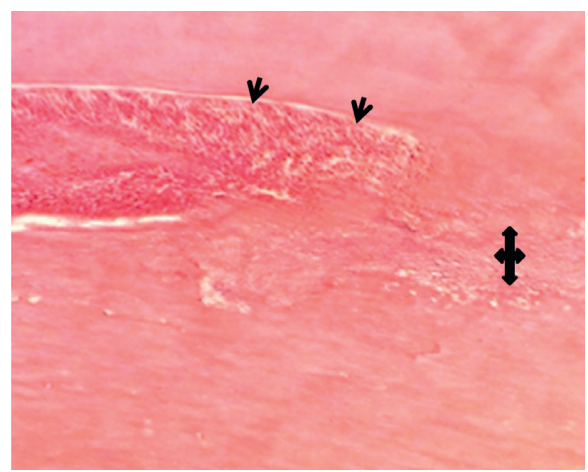

(b)

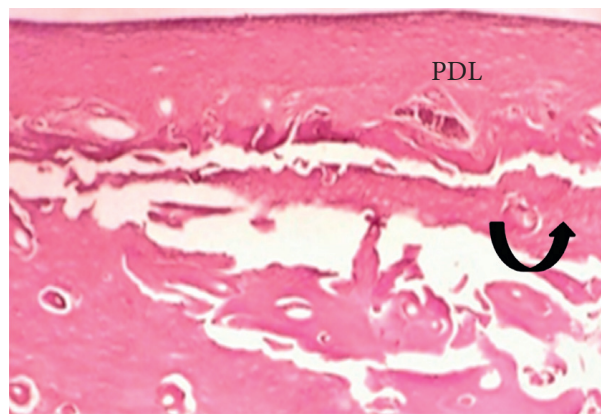

(c)

Figure 5: Microphotographs of an H\&E-stained longitudinal section through central incisor after 4 wks of Biodentine (BD) treatment. (a-b) A highly cellular pulp tissue obliterated by irregular deposition of reparative dentine (quad arrow) next to multiple layers of small-sized odontoblasts "Black arrow heads" (40X and 100X). (c) The periodontal ligament attached to a thin cementum layer had organized and dense fibrous bundles running parallel to the root surface (principle fibers) besides a few congested and dilated capillaries toward the bone side. There is no inflammatory cells infiltration. The gap in the alveolar bone was filled by multiple small trabeculae and a few vascular marrow tissues were continuous with adjacent bone (black curved up arrow) at the interface with PDL (200X).

phosphatase (ALP) enzyme express [60], and high vascular endothelial growth factor (VEGF) secretion level [61]. Furthermore, the host responses are influenced by the biomaterial properties, and presence of minor amounts of several metal oxides (aluminum, arsenic, beryllium, cadmium, chromium, and irons) in MM-MTA may be another potential draw back [62]. On the other hand, bioceramic products which formed from ESRRM putty contains only trace amount of aluminum, approximately one in thousands of the amount found in MM-MTA [63]. Moreover, presence of bismuth oxide as radiopacifier in MM-MTA does not encourage cell proliferation in cell culture and may increase cytotoxicity compared to the presence of zirconium oxide in $\mathrm{BD}$ and tantalum pentoxide in ESRRM putty $[11,55,64]$.

Similar results were obtained in the only published in vivo study conducted by Fouda et al. [65]. They assessed the effect of ESRRM putty on the pulp response and concluded that ESRRM putty can induce hard tissue formation to the wall of the exposure site. Moreover, in an in vitro study, Machado et al. [30] reported ESRRM putty and ProRoot MTA had similar rates of mouse dental pulp cells proliferation.

On the other hand, adequate information in line with our results is available both from in vitro and in vivo studies evaluating the effect of $\mathrm{BD}[23,56]$ or different formulations of MTA [66] on the response of the pulp-dentine complex.
Comparing the result of this study with that of other studies in pediatric dentistry, all three tested calcium silicatebased cements can be safely used as MTA in endodontics and pulp treatment [67-69]. As an alternative to MTA, MMMTA, BD, and ESRRM putty could be suitable due to ease of handling and application, as well as strength and biological effect which is similar to MTA.

Concurrently, our study focused on the effect of ESRRM putty, BD, and MM-MTA on the healing process in the PDL and the surrounding alveolar bone at the site of perforation facing the implanted material. The clinical efficacy of the material depends on its ability to stimulate cell proliferation or survival; this will likely promote the healing process. The results of the histopathologic evaluation showed that after one week, the injured area contained necrotic tissue and disorganized PDL infiltrated by chronic inflammatory cells for all tested groups. Previous in vitro studies had confirmed the good sealing ability of MTA (ProRootM) in repairing large $(1 \mathrm{~mm})$ furcation perforations of human molars $[70,71]$. Thus, the observed necrotic tissue cannot be attributed to bacterial invasion or the existence of lateral canals as in the case of furcation canals, but is possibly related to the mechanical injury produced during drilling. It is essential to declare that PDL necrosis was not associated with pulpal necrosis in any of the three calcium silicate materials. This is probably due to the abundant number of 


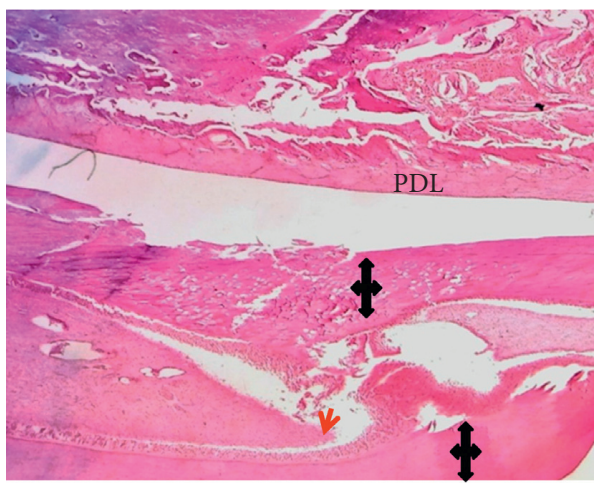

(a)

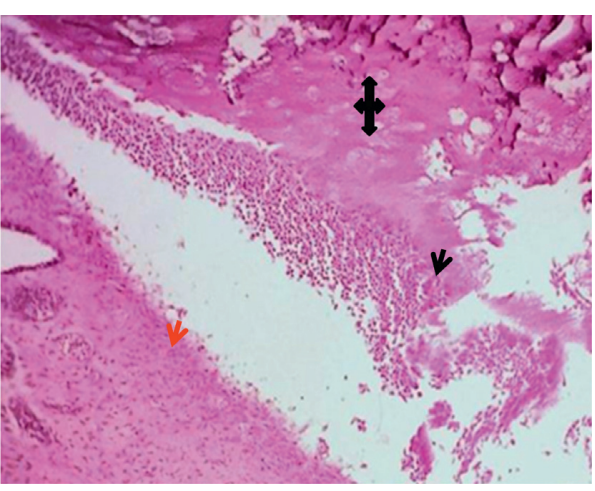

(b)

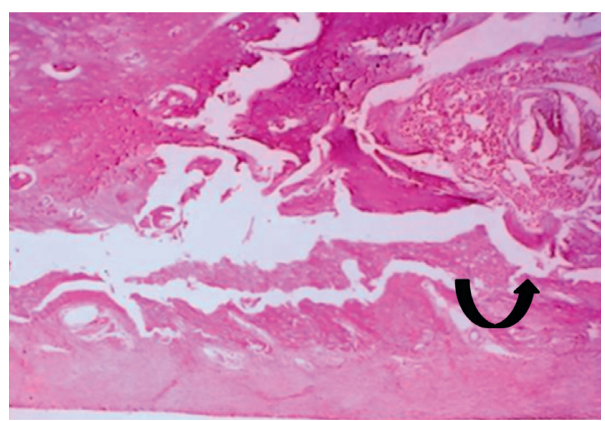

(c)

FIGURE 6: Microphotographs of longitudinal H\&E-stained sections through central incisor after 4 wks of MM-MTA treatment. (a-b) The pulpal tissue (red arrow heads) was highly cellular and contained a few dilated and congested blood vessels with no inflammatory cells infiltration and at the experimental site was lined by an area of reparative dentine deposition (quad arrows) with multilayers of short odontoblasts (black arrow head) ((a) 40X, (b) 100X). (C) The periodontal ligament had organized highly dense fibrous bundles running parallel to the root surface (principle fibers) and inserted in the newly formed bone (black curved-up arrow) with minimum congested capillaries and no inflammatory cells infiltration (100X). The gap in the alveolar bone was filled by multiple small trabeculae (black curvedup arrow) and large vascular marrow tissues besides the continuous interface with PDL.

stem cells and plentiful vascular supply within the pulp of rat incisor as it has an opened apex that has an effect on pulp vitality [50].

Nevertheless, the final outcome after one month affirmed the formation of dense fibrous tissue facing the site of the injured root surface that runs in continuity with the original collagen fibers within the PDL. Besides, some of these fibers mimicked Sharpey's fibers as they were inserted in the cementum-like tissue on the root surface, suggesting the regenerating and organization of the original tissue with continuous eruption in all cases of ESRRM putty without statistical differences in comparison with MM-MTA and BD subgroups.

Regarding the conductive ability of the materials in cortical plate healing after 4 weeks, the present study showed no significant difference among the ESRRM putty, BD, and MM-MTA; however, the ESRRM putty group showed more frequent samples with a complete closure of the hole by a thicker layer of new bone deposition than seen in the MMMTA and BD groups. This finding is consistent with that of a study conducted by Chen et al. [72]. They observed that six weeks after root-end microsurgery in dogs, ESRRM putty achieved a better PDL and bone-healing response histologically than MTA. ESRRM putty can induce osteoprogenitors to differentiate to mature osteoblasts more than
MTA and BD [73, 74]. Recently, Silva et al. [8] stated that although the thickness and area of newly formed mineralized tissue were significantly higher in MTA than BD, BD induced repair by the formation of mineralized tissue sealing, totally or partially, of the furcation perforations in most cases. Also, the osteogenic differentiation potential of human alveolar bone marrow stem cells and hard tissue formation was similar in MM-MTA, ProRoot MTA, and BD [75]. The differentiation of progenitor cells into osteoblastlike cells is essential in the bone healing process, and inducing cell differentiation is required for a biomaterial to be considered a root repair material [76]. The osteodifferentiation of MM-MTA related to increase in alkaline phosphatase activity [77] and the expression of bone morphogenetic protein 2 (BMP2) more than other generations of MTA, and this may be associated with higher concentration of magnesium and sodium [78]. The presence of higher silicon ions in BD stimulates young bone formation by stimulating osteoblasts and promoting mineralization [11].

Future studies are needed to clarify the detailed mechanism of how MM-MTA, BD, and ESRRM putty induced odontogenic proliferation, and osteogenic differentiation of mesenchymal stem cells over an extended treatment period with larger samples is highly recommended. 


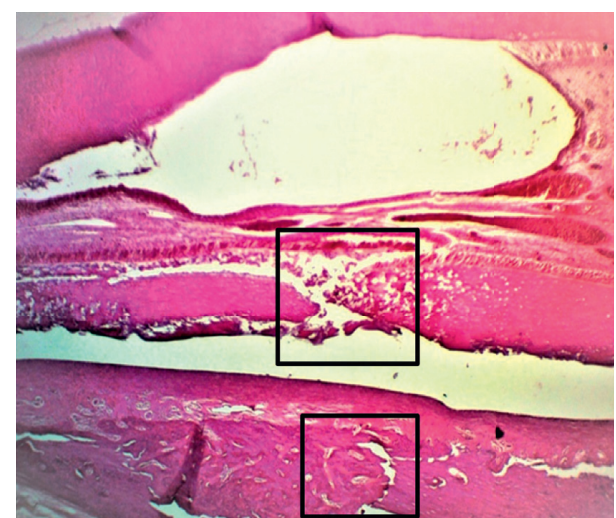

(a)

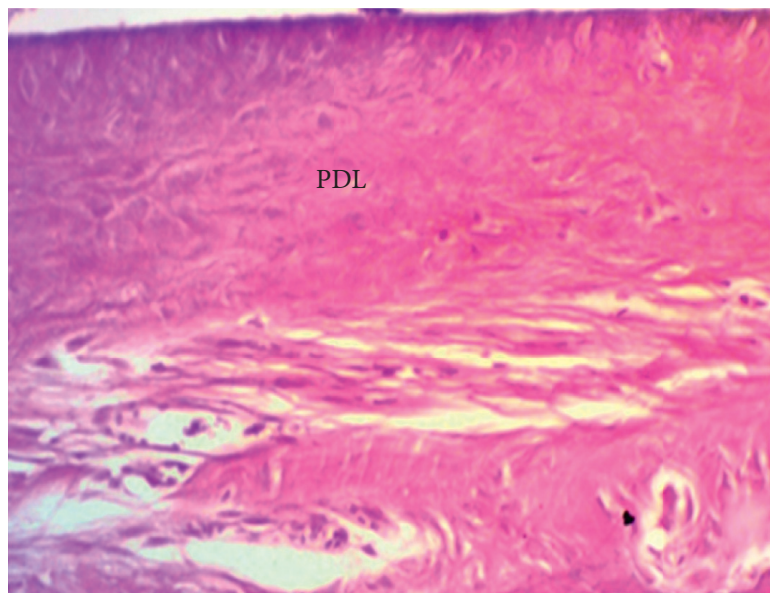

(d)

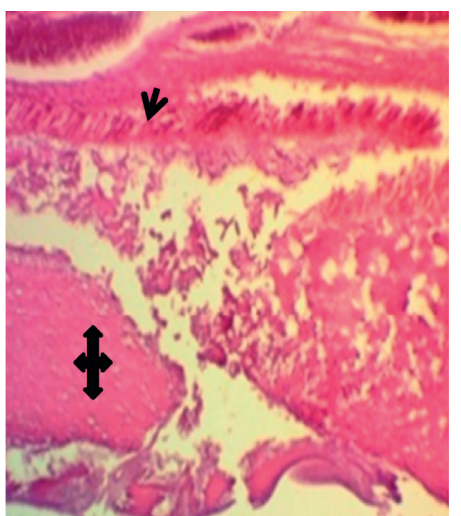

(b)

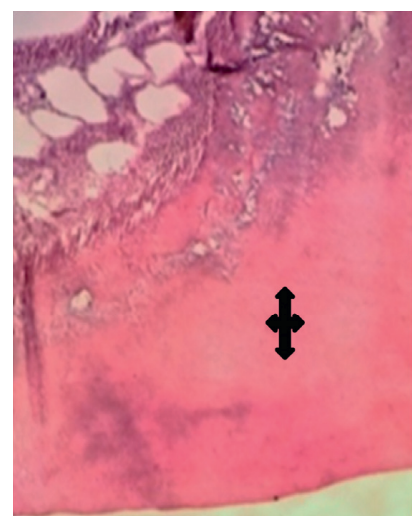

(c)

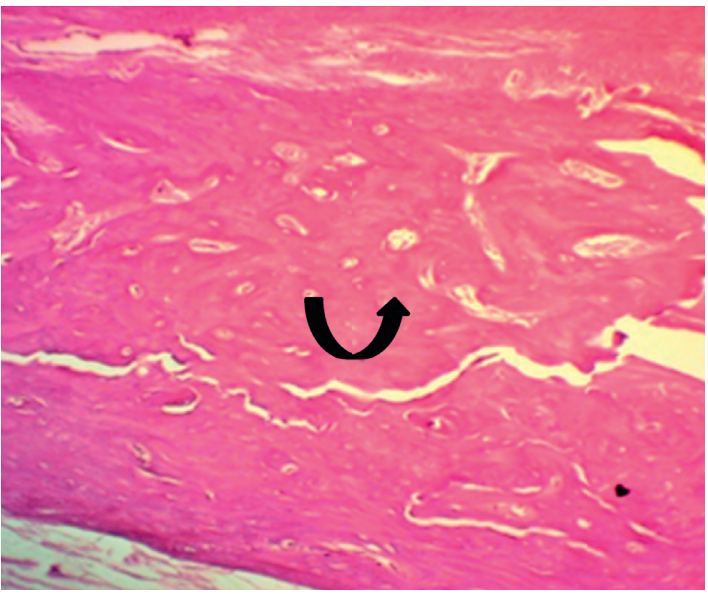

(e)

FIGURE 7: Microphotographs of longitudinal H\&E-stained sections through central incisor after 4 wks of ESRRM putty treatment. (a) The pulpal tissue contained a few long dilated and congested blood vessels, and an irregular deposition of reparative (quad arrows) dentine was seen adjacent to multilayers of short odontoblasts (black arrow head) ((a) 40X; (b-c) 100 X). (d) The periodontal ligament (PDL) had organized dense fibrous principle fibers bundles running parallel to the root surface and inserted in the newly formed bone with minimum congested capillaries and no inflammatory cells infiltration (400X). (e) The gap within the alveolar bone (black curved-up arrow) was filled with compact bone and bone marrow (400X).

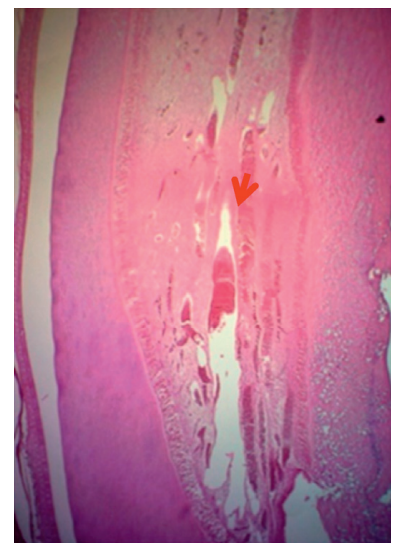

(a)

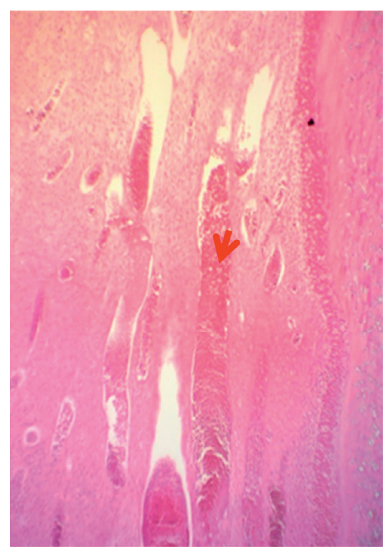

(b)

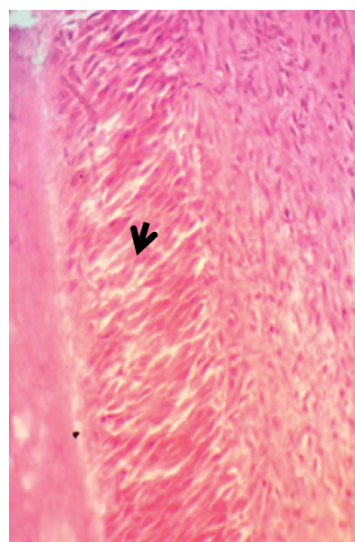

(c)

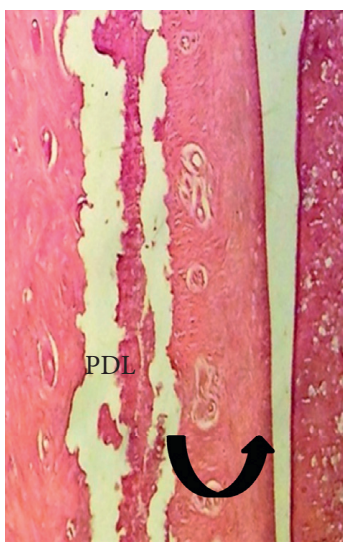

(d)

FiguRE 8: Microphotographs of an H\&E-stained longitudinal section through healthy nonperforated lower central incisors (control group). $(\mathrm{a}-\mathrm{c})$ The dental pulp (red arrow heads) showed long dilated congested blood vessels, cellular loose connective tissue, and multiple layers of palisaded columnar odontoblast (black arrow heads) cells adjacent to predentine (40X,100X, and 200X, respectively). (d) The periodontal ligament (PDL) attached to a thin cementum layer had organized dense fibrous bundles (principle fibers) separated by small areas of vascular connective fibrous tissue. There is no inflammatory cells infiltration. The alveolar bone (black curved up arrow) is compact-dense and contains osteocytes (100X). 


\section{Conclusion}

Under the limitation of this study, ESRRM putty had early signs of healing process and ended with recognized dentine and bone deposition, followed by MM-MTA and BD. All three calcium silicate-based cements exhibited good biocompatibility to pulp tissue and promoted regeneration of injured PDL and alveolar bone, inducing the proliferation of dental pulp cells and the formation of reparative dentine bridge that increased with time.

\section{Data Availability}

The data used to support the findings of this study are included within the article.

\section{Ethical Approval}

This article does not contain any studies with human participants or animals performed by any of the authors. All applicable international, national, and/or institutional guidelines for the care and use of animals were followed. All procedures performed in studies involving human participants were in accordance with the ethical standards of the institutional and/or national research committee and with the 1964 Helsinki Declaration and its later amendments or comparable ethical standards.

\section{Consent}

Informed consent was obtained from all individual participants included in the study.

\section{Conflicts of Interest}

The authors declare that there are no conflicts of interest.

\section{Acknowledgments}

The authors wish to thank Assistant Prof. Dr. Othman Jamal Nassrulla for his help and assistance with the surgeries. The work was supported by the Department of Conservative Dentistry College of Dentistry, University of Sulaimani, Kurdistan Region/Iraq, and Department of Dental Biomaterials Tehran University of Medical Sciences, Iran.

\section{References}

[1] I. Sinai, "Endodontic perforations: their prognosis and treatment," Journal of the American Dental Association, vol. 95, no. 1, pp. 90-95, 1997.

[2] S. Seltzer, I. Sinai, and D. August, "Periodontal effects of root perforations before and during endodontic procedures," Journal of Dental Research, vol. 49, no. 2, pp. 332-339, 1970.

[3] Z. Fuss and M. Trope, "Root perforations: classification and treatment choices based on prognostic factors," Dental Traumatology, vol. 12, no. 6, pp. 225-264, 1996.

[4] R. E. Walton and M. Torabinejad, Principles and Practice of Endodontics, Saunders Elsevier Publisher, Oxford, UK, 3rd edition, 2002.
[5] J. Mente, M. Leo, D. Panagidis, D. Saure, and T. Pfefferle, "Treatment outcome of mineral trioxide aggregate: repair of root perforations-long-term results," Journal of Endodontics, vol. 40, no. 6, pp. 790-796, 2014.

[6] S. Baek, H. Plenkjr Jr., and S. Kim, "Periapical tissue responses and cementum regeneration with amalgam, SuperEBA, and MTA as root-end filling materials," Journal of Endodontics, vol. 31, no. 6, pp. 444-449, 2005.

[7] J. L. Weldon Jr., D. H. Pashley, R. J. Loushine, R. N. Weller, and W. F. Kimbrough, "Sealing ability of mineral trioxide aggregate and super-EBA when used as furcation repair materials: a longitudinal study," Journal of Endodontics, vol. 28, no. 6, pp. 467-470, 2002.

[8] L. A. B. Silva, K. A. M. G. Pieroni, P. Nelson-Filho et al., "Furcation perforation: periradicular tissue response to biodentine as a repair material by histopathologic and indirect immunofluorescence analyses," Journal of Endodontics, vol. 43, no. 7, pp. 1137-1142, 2017.

[9] B. Buldur, F. Oznurhan, and A. Kaptan, "The effect of different chelating agents on the push-out bond strength of proroot MTAand endosequence root repair material," European Oral Research, vol. 53, no. 2, pp. 88-93, 2019.

[10] S.-J. Lee, M. Monsef, and M. Torabinejad, "Sealing ability of a mineral trioxide aggregate for repair of lateral root perforations," Journal of Endodontics, vol. 19, no. 11, pp. 541-544, 1993.

[11] C. Prati and M. G. Gandolfi, "Calcium silicate bioactive cements: biological perspectives and clinical applications," Dental Materials, vol. 31, no. 4, pp. 351-370, 2015.

[12] A. E. Dawood, P. Parashos, R. H. K. Wong, E. C. Reynolds, and D. J. Manton, "Calcium silicate-based cements: composition, properties, and clinical applications," Journal of Investigative and Clinical Dentistry, vol. 8, no. 2, pp. 1-15, 2017.

[13] E. T. Koh, F. McDonald, T. R. Pitt Ford, and M. Torabinejad, "Cellular response to mineral trioxide aggregate," Journal of Endodontics, vol. 24, no. 8, pp. 543-547, 1998.

[14] P. J. C. Mitchell, T. R. Pitt Ford, M. Torabinejad, and F. McDonald, "Osteoblast biocompatibility of mineral trioxide aggregate," Biomaterials, vol. 20, no. 2, pp. 167-173, 1999.

[15] N. Farsi, N. Alamoudi, K. Balto et al., "Clinical assessment of mineral trioxide aggregate (MTA) as direct pulp capping in young permanent teeth," Journal of Clinical Pediatric Dentistry, vol. 31, no. 2, pp. 72-76, 2006.

[16] M. Vallés, M. Mercadé, F. Duran-Sindreu, J. L. Bourdelande, and M. Roig, "Color stability of white mineral trioxide aggregate," Clinical Oral Investigations, vol. 17, no. 4, pp. 1155-1159, 2013.

[17] J. Camilleri, F. E. Montesin, S. Papaioannou, F. McDonald, and T. R. Pitt Ford, "Biocompatibility of two commercial forms of mineral trioxide aggregate," International Endodontic Journal, vol. 37, no. 10, pp. 699-704, 2004.

[18] S. Köseoğlu, K. T. Pekbağr Yan, E. Kucukyilmaz, M. Sağlam, S. Enhos, and A. Akgün, "Biological response of commercially available different tricalcium silicate-based cements and pozzolan cement," Microscopy Research and Technique, vol. 80, no. 9, pp. 994-999, 2017.

[19] H.-m. Zhou, Y. Shen, Z.-j. Wang et al., "In vitro cytotoxicity evaluation of a novel root repair material," Journal of Endodontics, vol. 39, no. 4, pp. 478-483, 2013.

[20] S. Rajasekharan, L. C. Martens, R. G. E. C. Cauwels, and R. M. H. Verbeeck, "Biodentine material characteristics and clinical applications: a review of the literature," European 
Archives of Paediatric Dentistry, vol. 15, no. 3, pp. 147-158, 2014.

[21] T. S. da Fonseca, G. F. da Silva, M. Tanomaru-Filho, E. SassoCerri, J. M. Guerreiro-Tanomaru, and P. S. Cerri, "In vivoevaluation of the inflammatory response and IL-6 immunoexpression promoted by Biodentine and MTA Angelus," International Endodontic Journal, vol. 49, no. 2, pp. 145-153, 2016.

[22] S. Jung, J. Mielert, J. Kleinheinz, and T. Dammaschke, "Human oral cells' response to different endodontic restorative materials: an in vitro study," Head \& Face Medicine, vol. 10, no. 1, pp. 55-64, 2014.

[23] P. Laurent, J. Camps, and I. About, "BiodentineTM induces TGF- $\beta 1$ release from human pulp cells and early dental pulp mineralization," International Endodontic Journal, vol. 45, no. 5, pp. 439-448, 2012.

[24] L. Han and T. Okiji, "Uptake of calcium and silicon released from calcium silicate-based endodontic materials into root canal dentine," International Endodontic Journal, vol. 44, no. 12, pp. 1081-1087, 2011.

[25] A. Nowicka, M. Lipski, M. Parafiniuk et al., "Response of human dental pulp capped with Biodentine and mineral trioxide aggregate," Journal of Endodontics, vol. 39, no. 6, pp. 743-747, 2013.

[26] T. Charland, G. R. Hartwell, C. Hirschberg, and R. Patel, “An evaluation of setting time of mineral trioxide aggregate and EndoSequence root repair material in the presence of human blood and minimal essential media," Journal of Endodontics, vol. 39, no. 8, pp. 1071-1072, 2013.

[27] N. A. Taha, R. A. Safadi, and M. S. Alwedaie, "Biocompatibility evaluation of EndoSequence root repair paste in the connective tissue of rats," Journal of Endodontics, vol. 42, no. 10 , pp. 1523-1528, 2016.

[28] A. Z. Alanezi, J. Jiang, K. E. Safavi, L. S. Spangberg, and Q. Zhu, "Cytotoxicity evaluation of endosequence root repair material," Oral Surgery Oral Medicine Oral Pathology Oral Radiology and Endodontology, vol. 109, no. 3, pp. 122-125, 2010.

[29] J. Ma, Y. Shen, S. Stojicic, and M. Haapasalo, "Biocompatibility of two novel root repair materials," Journal of Endodontics, vol. 37, no. 6, 2011.

[30] J. Machado, J. D. Johnson, and A. Paranjpe, "The effects of endosequence root repair material on differentiation of dental pulp cells," Journal of Endodontics, vol. 42, no. 1, pp. 101-105, 2016.

[31] S. Liu, S. Wang, and Y. Dong, "Evaluation of a bioceramic as a pulp capping agent in vitro and in vivo," Journal of Endodontics, vol. 41, no. 5, pp. 652-657, 2015.

[32] M. A. Salman, F. Quinn, J. Dermody, D. Hussey, and N. Claffey, "Histological evaluation of repair using a bioresorbable membrane beneath a resin-modified glass ionomer after mechanical furcation perforation in dogs' teeth," Journal of Endodontics, vol. 25, no. 3, pp. 181-186, 1999.

[33] T. R. Moretton, C. E. Brown Jr., J. J. Legan, and A. H. Kafrawy, "Tissue reactions after subcutaneous and intraosseous implantation of mineral trioxide aggregate and ethoxybenzoic acid cement," Journal of Biomedical Materials Research, vol. 52, no. 3, pp. 528-533, 2000.

[34] M. N. Aydin and B. Buldur, "The effect of intracanal placement of various medicaments on the bond strength of three calcium silicate-based cements to root canal dentin," Journal of Adhesion Science and Technology, vol. 32, no. 5, pp. 542552,2018
[35] K. Siew, A. H. C. Lee, and G. S. P. Cheung, "Treatment outcome of repaired root perforation: a systematic review and meta-analysis," Journal of Endodontics, vol. 41, no. 11, pp. 1795-1804, 2015.

[36] R. Srinivasan, N. Bhagabati, A. Rajput, and S. Akhtar, "Nonsurgical repair of iatrogenic furcal perforation of radix entomolaris," Medical Journal Armed Forces India, vol. 71, no. 2, pp. 422-424, 2015.

[37] S.-Y. Cho, D.-G. Seo, S.-J. Lee, J. Lee, S.-J. Lee, and I.-Y. Jung, "Prognostic factors for clinical outcomes according to time after direct pulp capping," Journal of Endodontics, vol. 39, no. 3, pp. 327-331, 2013.

[38] B. Buldur, F. Öznurhan, M. Kayabaşi, and F. Şahin, "Shear bond strength of two calcium silicate-based cements to compomer," Cumhuriyet Dental Journal, vol. 21, no. 1, pp. 18-23, 2018.

[39] P. Mehrvarzfar, P. V. Abbott, F. Mashhadiabbas, M. Vatanpour, and S. Tour Savadkouhi, "Clinical and histological responses of human dental pulp to MTA and combined MTA/treated dentin matrix in partial pulpotomy," Australian Endodontic Journal, vol. 44, no. 1, pp. 46-53, 2018.

[40] M. Daoudi and W. Saunders, "In vitro evaluation of furcal perforation repair using mineral trioxide aggregate or resin modified glass ionomer cement with and without the use of the operating microscope," Journal of Endodontics, vol. 28, no. 7, pp. 512-515, 2002.

[41] Y. Wu, R. C. Zhao, and E. E. Tredget, "Concise review: bone marrow-derived stem/progenitor cells in cutaneous repair and regeneration," Stem Cells, vol. 28, no. 5, pp. 905-915, 2010.

[42] R. Pace, V. Giuliani, and G. Pagavino, "Mineral trioxide aggregate as repair material for furcal perforation: case series," Journal of Endodontics, vol. 34, no. 9, pp. 1130-1133, 2008.

[43] C. Main, N. Mirzayan, S. Shabahang, and M. Torabinejad, "Repair of root perforations using mineral trioxide aggregate: a long-term study," Journal of Endodontics, vol. 30, no. 2, pp. $80-83,2004$.

[44] R. A. Beavers, G. Bergenholtz, and C. F. Cox, "Periodontal wound healing following intentional root perforations in permanent teeth of Macaca mulatta," International Endodontic Journal, vol. 19, no. 1, pp. 36-44, 1986.

[45] T. Dammaschke, "Rat molar teeth as a study model for direct pulp capping research in dentistry," Laboratory Animals, vol. 44 , no. 1, pp. 1-6, 2010.

[46] M. J. B. Silva, M. V. Caliari, A. P. R. Sobrinho, L. Q. Vieira, and R. M. E. Arantes, "Anin vivoexperimental model to assess furcal lesions as a result of perforation," International Endodontic Journal, vol. 42, no. 10, pp. 922-929, 2009.

[47] A. Al-Daafas and S. Al-Nazhan, "Histological evaluation of contaminated furcal perforation in dogs' teeth repaired by MTA with or without internal matrix," Oral Surgery Oral Medicine Oral Pathology Oral Radiology and Endodontology, vol. 103, no. 3, pp. 92-99, 2007.

[48] G. R. Hartwell and M. C. England, "Healing of furcation perforations in primate teeth after repair with decalcified freeze-dried bone: a longitudinal study," Journal of Endodontics, vol. 19, no. 7, pp. 357-361, 1993.

[49] R. K. Scarparo, L. Dondoni, D. E. Böttcher, F. S. Grecca, M. I. B. Rockenbach, and E. L. Batista, "Response to intracanal medication in immature teeth with pulp necrosis: an experimental model in rat molars," Journal of Endodontics, vol. 37, no. 8, pp. 1069-1073, 2011. 
[50] H. Harada and H. Ohshima, "New perspectives on tooth development and the dental stem cell niche," Archives of Histology and Cytology, vol. 67, no. 1, pp. 1-11, 2004.

[51] M. Cajazeira Aguiar and V. E. Arana-Chavez, "Ultrastructural and immunocytochemical analyses of osteopontin in reactionary and reparative dentine formed after extrusion of upper rat incisors," Journal of Anatomy, vol. 210, no. 4, pp. 418-427, 2007.

[52] R. C. Bielby, I. S. Christodoulou, R. S. Pryce, W. J. P. Radford, L. L. Hench, and J. M. Polak, "Time- and concentrationdependent effects of dissolution products of $58 \mathrm{~S}$ sol-gel bioactive glass on proliferation and differentiation of murine and human osteoblasts," Tissue Engineering, vol. 10, no. 7-8, pp. 1018-1026, 2004.

[53] W. R. Hirschman, M. A. Wheater, J. S. Bringas, and M. M. Hoen, "Cytotoxicity comparison of three current direct pulp-capping agents with a new bioceramic root repair putty," Journal of Endodontics, vol. 38, no. 3, pp. 385-388, 2012.

[54] B. A. Damas, M. A. Wheater, J. S. Bringas, and M. M. Hoen, "Cytotoxicity comparison of mineral trioxide aggregates and EndoSequence bioceramic root repair materials," Journal of Endodontics, vol. 37, no. 3, pp. 372-375, 2011.

[55] R. M. Talabani, B. T. Garib, and R. Masaeli, "Biocompatibility of three calcium silicate based materials implanted in rat subcutaneous tissue," Biomedical Research, vol. 30, no. 4, pp. 591-599, 2019.

[56] X. V. Tran, C. Gorin, C. Willig et al., "Effect of a calciumsilicate-based restorative cement on pulp repair," Journal of Dental Research, vol. 91, no. 12, pp. 1166-1171, 2012.

[57] N. Kawashima and T. Okiji, "Odontoblasts: specialized hardtissue-forming cells in the dentin-pulp complex," Congenital Anomalies, vol. 56, no. 4, pp. 144-153, 2016.

[58] I. Chen, I. Salhab, F. C. Setzer, S. Kim, and H.-D. Nah, “A new calcium silicate-based bioceramic material promotes human osteo- and odontogenic stem cell proliferation and survival via the extracellular signal-regulated kinase signaling pathway," Journal of Endodontics, vol. 42, no. 3, pp. 480-486, 2016.

[59] S. W. Hansen, J. G. Marshall, and C. M. Sedgley, "Comparison of intracanal EndoSequence root repair material and ProRoot MTA to induce $\mathrm{pH}$ changes in simulated root resorption defects over 4 weeks in matched pairs of human teeth," Journal of Endodontics, vol. 37, no. 4, pp. 502-506, 2011.

[60] T. X. Li, J. Yuan, Y. Chen et al., "Differentiation of mesenchymal stem cells from human umbilical cord tissue into odontoblast-like cells using the conditioned medium of tooth germ cells in vitro," Biomed Research International, vol. 2013, Article ID 218543, p. 10, 2013.

[61] A. Paranjpe, N. Cacalano, W. Hume, and A. Jewett, "Nacetylcysteine protects dental pulp stromal cells from HEMAinduced apoptosis by inducing differentiation of the cells," Free Radical Biology and Medicine, vol. 43, no. 10, pp. 1394-1408, 2007.

[62] S. Azimi, M. Fazlyab, D. Sadri, M. A. Saghiri, B. Khosravanifard, and S. Asgary, "Comparison of pulp response to mineral trioxide aggregate and a bioceramic paste in partial pulpotomy of sound human premolars: a randomized controlled trial," International Endodontic Journal, vol. 47, no. 9, pp. 873-881, 2014.

[63] K. Y. Kum, E.-C. Kim, Y.-J. Yoo et al., "Trace metal contents of three tricalcium silicate materials: MTA Angelus, Micro Mega MTA and Bioaggregate," International Endodontic Journal, vol. 47, no. 7, pp. 704-710, 2014.
[64] G. Debelian and M. Trope, "The use of premixed bioceramic materials in endodontics," Giornale Italiano di Endodonzia, vol. 30, no. 2, pp. 70-80, 2016.

[65] M. Y. Fouda, K. G. Abdel-Kader, and M. A. Abdel Hamid, “A histological evaluation of root repair material and mineral trioxide aggregate in inducing calcified dentine barrier in exposed mature pulps of dog's teeth," Egypt Dental Journal, vol. 60, no. 2, pp. 2401-2407, 2014.

[66] I. T. Khalil, T. Sarkis, and A. Naaman, "MM-MTA for direct pulp capping: a histologic comparison with ProRoot MTA in rat molars," Journal of Contemporary Dental Practice, vol. 14, no. 6, pp. 1019-1023, 2013.

[67] O. Carti and F. Oznurhan, "Evaluation and comparison of mineral trioxide aggregate and biodentine in primary tooth pulpotomy: clinical and radiographic study," Nigerian Journal of Clinical Practice, vol. 20, no. 12, pp. 1604-1609, 2017.

[68] J. C. Abou Chedid, N. Mchayleh, I. Khalil, B. Melki, and L. S. Hardan, "An 18 month evaluation of MM-MTA pulpotomy on primary decayed molars," Tropical Dental Journal, vol. 38, no. 152, pp. 17-24, 2015.

[69] A. Madfa, F. A. Al-Sanabani, and N. H. Al-Qudami AlKudami, "Endodontic repair filling materials: a review article," British Journal of Medicine and Medical Research, vol. 4, no. 16, pp. 3059-3079, 2014.

[70] D. V. Tsatsas, H. A. Meliou, and N. P. Kerezoudis, "Sealing effectiveness of materials used in furcation perforation in vitro," International Dental Journal, vol. 55, no. 3, pp. 133$141,2005$.

[71] G. Lodiene, M. Kleivmyr, E. Bruzell, and D. Orstavik, "Sealing ability of mineral trioxide aggregate, glass ionomer cement and composite resin when repairing large furcal perforations," Britih Dental Journal, vol. 210, no. 5, pp. 1-7, 2011.

[72] I. Chen, B. Karabucak, C. Wang et al., "Healing after root-end microsurgery by using mineral trioxide aggregate and a new calcium silicate-based bioceramic material as root-end filling materials in dogs," Journal of Endodontics, vol. 41, no. 3, pp. 389-399, 2015.

[73] H. S. Rifaey, M. Villa, Q. Zhu, Y.-H. Wang, K. Safavi, and I.-P. Chen, "Comparison of the osteogenic potential of mineral trioxide aggregate and endosequence root repair material in a 3-dimensional culture system," Journal of Endodontics, vol. 42, no. 5, pp. 760-765, 2016.

[74] N. Sultana, M. Singh, R. R. Nawal et al., "Evaluation of biocompatibility and osteogenic potential of tricalcium silicate-based cements using human bone marrow-derived mesenchymal stem cells," Journal of Endodontics, vol. 44, no. 3, pp. 446-451, 2018.

[75] S. Margunato, P. N. Taşlı, S. Aydın, M. Karapınar Kazandağ, and F. Şahin, "In vitro evaluation of ProRoot MTA, biodentine, and MM-MTA on human alveolar bone marrow stem cells in terms of biocompatibility and mineralization," Journal of Endodontics, vol. 41, no. 10, pp. 1646-1652, 2015.

[76] B.-N. Lee, K.-N. Lee, J.-T. Koh et al., "Effects of 3 endodontic bioactive cements on osteogenic differentiation in mesenchymal stem cells," Journal of Endodontics, vol. 40, no. 8, pp. 1217-1222, 2014.

[77] E. Onay, E. Yurtcu, Y. Terzi, M. Ungor, Y. Oguz, and F. Sahin, "Odontogenic effects of two calcium silicate-based biomaterials in human dental pulp cells," Advances in Clinical and Experimental Medicine, vol. 27, no. 11, pp. 1541-1547, 2018.

[78] H. M. Setbon, J. Devaux, A. Iserentant, G. Leloup, and J. G. Leprince, "Influence of composition on setting kinetics of new injectable and/or fast setting tricalcium silicate cements," Dental Materials, vol. 30, no. 12, pp. 1291-1303, 2014. 